\title{
Orbital fibroblast chemokine modulation: effects of dexamethasone and cyclosporin $\mathrm{A}$
}

\author{
Michael A Burnstine, Susan G Elner, Victor M Elner
}

\begin{abstract}
Aim-Orbital inflammation is common, but the mechanisms underlying leucocytic infiltration of orbital tissue are poorly understood. Human orbital fibroblasts (OF) express chemokines, interleukin 8 (IL-8) and monocyte chemotactic protein 1 (MCP-1), when exposed to proinflammatory cytokines. The effects of dexamethasone (DEX) and cyclosporin A (CSA) on OF IL-8 and MCP-1 were examined.

Methods-Cultured human OF were incubated with recombinant interleukin $1 \beta$

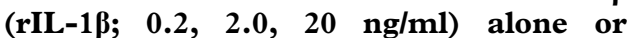
incubated with rIL-1 $\beta$ and DEX $\left(10^{-8}, 10^{-7}\right.$, $\left.10^{-6} \mathrm{M}\right)$ or CSA $(3,30,300 \mathrm{ng} / \mathrm{ml})$ for 24 hours. ELISA and northern blot analyses were performed to determine OF IL-8 and MCP-1 protein secretion and MRNA expression, respectively.

Results-OF lacked constitutive IL-8 or MCP-1 expression, but secreted significant amounts of these chemokines and expressed substantial steady state mRNA

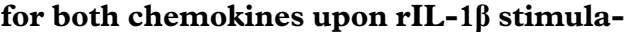
tion. DEX caused dose dependent inhibition of IL-1 induced IL-8 $(p<0.001)$ and MCP-1 $(p<0.05)$ secretion and mRNA

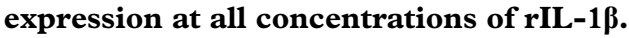
CSA enhanced IL-1 induced OF IL-8 $(p<0.001)$ and suppressed $r I L-1 \beta$ induced OF MCP-1 $(p<0.05)$ secretion when lower doses of $\mathrm{rIL}-1 \beta$ were used. These effects on secreted chemokines at different concentrations of rIL-1 $\beta$ and immunomodulating agents were corroborated by steady state OF IL-8 and MCP-1 mRNA expression. Conclusions-DEX is a potent inhibitor of OF IL-8 and MCP-1. In contrast, CSA enhances IL-1 induced OF IL-8 and suppresses OF MCP-1. These observations may explain the relative lack of CSA effectiveness in human orbital diseases that respond to corticosteroids.

(Br f Ophthalmol 1998;82:318-322)
\end{abstract}

Department of Pathology, The University of Michigan Medical School, Ann

Arbor

V M Elner

Correspondence to: Michael A Burnstine, MD, Doheny Eye Institute,

University of Southern California, 1450 San Pablo Street, Los Angeles, CA 90033, USA.

Accepted for publication 10 October 1997

Orbital inflammation accounts for approximately $57 \%$ of all orbital disorders. ${ }^{1}$ These disorders, characterised by inflammatory cell infiltrates, include orbital cellulitis, orbital myositis, Graves' eye disease, idiopathic orbital inflammation (orbital pseudotumour), as well as inflammation associated with systemic diseases. The mechanisms mediating orbital inflammation, however, remain poorly understood. ${ }^{2-}$

Infiltration of leucocytes into inflamed tissue is a complex phenomenon, probably orches- trated by chemotactic gradients expressed via cytokine cascades. We believe that resident orbital cells may participate in the initiation and perpetuation of many orbital inflammatory disease processes. We have shown that orbital fibroblasts $(\mathrm{OF})$ secrete mediators that may be crucial to orchestrating orbital immune and inflammatory responses. ${ }^{5}$ Specifically, stimulation with lipopolysaccharide (LPS) or recombinant ( $r$ ) proinflammatory cytokines (interleukin $1 \beta$ (rIL-1 $\beta$ ), tumour necrosis factor $\alpha$ $(\mathrm{rTNF}-\alpha)$, or interferon $\gamma(\mathrm{rIFN}-\gamma))$ induces secretion of different $\mathrm{OF}$ chemokines, low molecular weight, proinflammatory cytokines that (1) chemoattract and activate distinct leucocyte subsets and (2) participate in the upregulation of inflammatory responses. ${ }^{6-8}$ Interleukin 8 (IL-8) and monocyte chemotactic protein 1 (MCP-1) are the two most potent and best characterised members of the superfamily of low molecular weight CXC and CC leucocyte chemokines, respectively. Induced principally by IL- 1 , TNF, and LPS, IL- 8 preferentially chemoattracts and activates neutrophils, while MCP-1 attracts and stimulates monocytes and lymphocytes. ${ }^{8}$ Thus, OF are anatomically well positioned and are functionally able to participate in the regulation of leucocyte movement and activation in diseased orbital tissue when exposed to ambient proinflammatory cytokines.

The production of novel chemotactic cytokines by $\mathrm{OF}$ is noteworthy because coordinating communication between the interstitium and vascular bed may dictate the initiation, maintenance, and resolution phases of orbital inflammation. Strategies aimed at modulating these potent leucocyte chemoattractant and activating agents may be helpful in the control of orbital inflammatory disease. To examine the effects of the immunosuppressive agents dexamethasone (DEX) and cyclosporin A (CSA), cultured human OF were co-incubated with these immunosuppressive agents and rIL$1 \beta$, a known inducer of IL- 8 and MCP-1. OF IL-8 and MCP-1 protein secretion was measured and steady state mRNA expression was analysed.

\section{Methods}

ORBITAL FIBROBLASTS AND STIMULATION WITH rIL-1B AND IMMUNOMODULATING AGENTS Human retro-ocular OF were obtained from the posterior surface of globes enucleated for uveal malignant melanoma by gently mincing orbital fat in Dulbecco's modified essential medium (DMEM) containing 15\% fetal bovine serum. The $\mathrm{OF}$ were grown at $37^{\circ} \mathrm{C}$ and $5 \%$ carbon dioxide and were passaged by 
trypsinisation and maintained in $25 \mathrm{~cm}^{2}$ tissue flasks for up to three passages. Experimental incubations were begun by simultaneously overlying newly confluent OF cultures with serum free media alone or in the same media containing DEX alone, CSA alone, or rIL-1 $\beta$ (Upjohn Company, Kalamazoo, MI, USA; 0.2, 2.0, and $20 \mathrm{ng} / \mathrm{ml}$ ) either alone or with DEX (Sigma Chemical Company, St Louis, MO, USA; $10^{-8}, 10^{-7}, 10^{-6} \mathrm{M}$ ) or CSA (Sigma Chemical Company; 3, 30, $300 \mathrm{ng} / \mathrm{ml}$ ) for 24 hours at $37^{\circ} \mathrm{C}$ and $5 \%$ carbon dioxide. The dosages of DEX and CSA were specifically used because they represent the drug concentrations at the cellular level: calculated dosage in total body water. The 24 hour time point was chosen based upon previous dose response and time course studies that indicated upregulation of IL-8 and MCP- $1 .{ }^{5}$ The specific activity of rIL- $1 \beta$ was 30 units/ng. After experimental incubations, the orbital fibroblast culture media were collected after centrifugation and stored at $-70^{\circ} \mathrm{C}$ until ELISA assays for IL-8 or MCP-1 were performed. Cell monolayers were extracted for IL- 8 and MCP-1 mRNA analyses.

IL-8 AND MCP-1 ELISA

Immunoreactive IL- 8 or MCP was measured in $\mathrm{OF}$ supernatants using a modification of the double ligand ELISA method. ${ }^{9}{ }^{10}$ Briefly, flat bottomed, 96 well microtitre plates (Nunc Immuno-Plate, Vanguard International, Neptune, NJ, USA) were coated with either rabbit anti-IL-8 or anti-MCP-1 antibodies, each at 1 $\mathrm{ng} / \mu \mathrm{l}$ in $0.6 \mathrm{M} \mathrm{NaCl}, 0.26 \mathrm{M} \mathrm{H}_{3} \mathrm{BO}_{4}$, and 0.08 $\mathrm{N} \mathrm{NaOH}(\mathrm{pH} 9.6)$, at $4^{\circ} \mathrm{C}$ and then washed with PBS (pH 7.5) and $0.05 \%$ Tween 20 (wash buffer). These antibodies were raised in rabbits using rIL-8 and rMCP-1 as previously described. ${ }^{9} 10$ These antibodies were exhaustively tested against numerous other chemokines, including other chemokines within the CC and CXC families; they were found to be very specific with no cross reactivity. Microtitre plate non-specific binding sites were blocked with $2 \%$ bovine serum albumin in PBS and incubated for 90 minutes at $37^{\circ} \mathrm{C}$. Plates were rinsed four times with wash buffer and diluted. Non-diluted (neat) and diluted (1:5 and 1:10) OF derived conditioned media $(50 \mu \mathrm{l})$ in duplicate were added and incubated for 1 hour at $37^{\circ} \mathrm{C}$. Plates were washed four times with wash buffer, then $50 \mu \mathrm{l} /$ well of biotinylated rabbit anti-IL-8 (1:2000) or anti-MCP-1 $(1: 2000)$ were added for 30 minutes at $37^{\circ} \mathrm{C}$. Plates were washed four times, streptavidinperoxidase conjugate (Bio-Rad, Richmond, CA, USA) was added, and the plates were incubated for 30 minutes at $37^{\circ} \mathrm{C}$. Plates were washed four times, chromogen substrate (BioRad) was added, the plates incubated to the desired extinction at room temperature, and the reaction terminated with $50 \mu \mathrm{l} /$ well of $3 \mathrm{M}$ $\mathrm{H}_{2} \mathrm{SO}_{4}$. Absorbance for each well at $490 \mathrm{~nm}$ was read in the ELISA reader. Standards were run with each ELISA and were calibrated using rIL-8 and rMCP-1 WHO standards: 1:2 $\log$ dilutions standards of rIL- 8 or rMCP-1 concentrations ranging from $1 \mathrm{pg}$ to $1000 \mathrm{ng}$ per well. This ELISA method consistently detected IL-8 or MCP-1 concentrations greater than $10 \mathrm{pg} / \mathrm{ml}$ in a linear fashion.

NORTHERN BLOT ANALYSIS OF OF IL-8 AND MCP-1 MRNA

Total OF cell RNA was extracted. ${ }^{11}{ }^{12}$ Adherent OF were solubilised in $25 \mathrm{mM}$ TRIS (pH 8.0) containing $4.2 \mathrm{M}$ guanidine isothiocyanate, 9.5\% Sarkosyl, and 0.1 M $\beta$-mercaptoethanol. An equal volume of $100 \mathrm{mM}$ TRIS ( $\mathrm{pH}$ 8.0) containing $1 \%$ SDS and $10 \mathrm{mM}$ EDTA was added and the RNA extracted with chloroform phenol. The alcohol precipitated RNA was separated by formaldehyde $1 \%$ agarose gels and transblotted to nitrocellulose. The baked blots were prehybridised and then hybridised with either a $\gamma^{32} \mathrm{P}-5$ end labelled (ICN Biomedicals, Inc, Costa Mesa, CA, USA), 30-mer oligonucleotide probe complementary to either nucleotides $262-291$ of the published cDNA sequence for IL-8 (5'-GTT-GGCGCA-GTG-TGG-TCC-ACT-CTC-AATCAC-3' $)^{13}$ or to nucleotides $256-285$ of the published cDNA sequence for MCP-1 (5'TTG-GGT-TTG-CTT-GTC-CAG-GTGGTC-CAT-GGA-3'). ${ }^{14}$ The blots were stringency washed and autoradiographed. Equivalent amounts of total RNA loaded per gel lane were assessed by monitoring $28 \mathrm{~s}$ and $18 \mathrm{~s}$ rRNA, comparing the fluorescence of the northern blot lanes stained with ethidium bromide.

STATISTICAL ANALYSIS

Individual experiments were performed in triplicate on three different OF cell lines (nine times) and the results composited. The mean IL-8 or MCP-1 concentrations plus or minus standard error of the mean (SEM) were determined for each assay condition and quantitated. Various assay conditions were compared using Student's $t$ test (two tailed) and probability values less than 0.05 were considered to be statistically significant.

\section{Results}

IL-8 AND MCP-1 ELISA ASSAYS OF HUMAN ORBITAL FIBROBLAST CELL SUPERNATANTS

OF lacked constitutive IL- 8 and MCP-1 secretion in control media or culture with DEX alone or CSA alone. When exposed to rIL-1 $\beta$ (20 ng/ml) for 24 hours, OF IL-8 and MCP-1 secretion increased as quantitated by ELISA (Figs 1 and 2 ; p <0.001). DEX produced dose dependent inhibition of both rIL-1 $\beta$ induced OF IL-8 $(p<0.001)$ and MCP-1 $(p<0.05)$, the greatest effect noted with DEX $10^{-6} \mathrm{M}$. Similar effects of DEX on OF IL-8 and MCP-1 production were noted when lower rIL-1 $\beta$ concentrations were used to induce these chemokines (Table 1 ).

Low $(3 \mathrm{ng} / \mathrm{ml}$ ) and moderate $(30 \mathrm{ng} / \mathrm{ml})$ doses of CSA augmented rIL- $1 \beta$ induced IL- 8 protein secretion at all doses of rIL- $1 \beta$ stimulation (Fig 1; Table 1). High dose CSA (300 $\mathrm{ng} / \mathrm{ml}$ ) was toxic and resulted in OF lysis. OF MCP-1 secretion induced by high dose rIL-1 $\beta$ $(20 \mathrm{ng} / \mathrm{ml})$ was not significantly altered by the presence of CSA (Fig 2). Low $(0.2 \mathrm{ng} / \mathrm{ml})$ and 


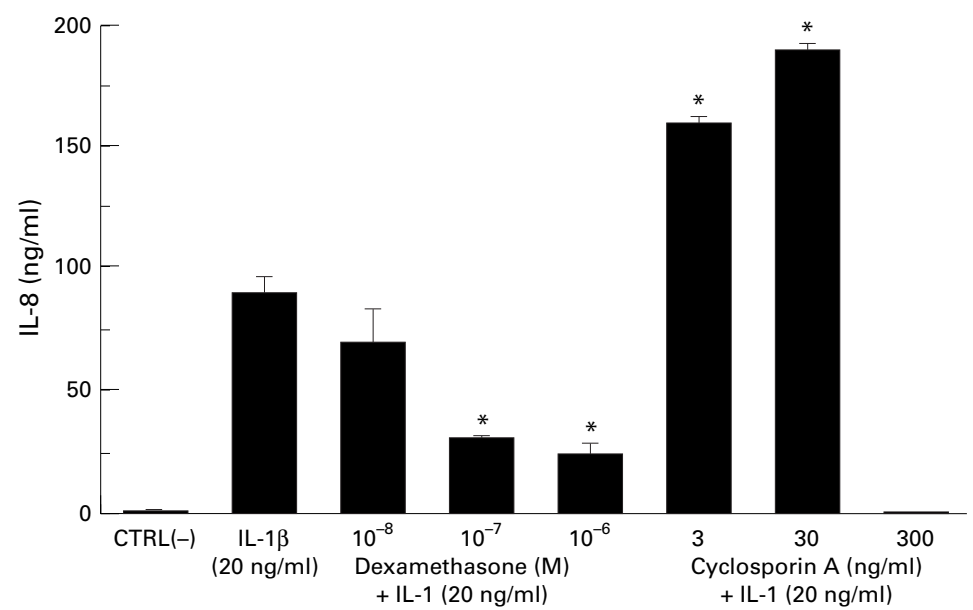

Figure 1 Dose dependent effects of dexamethasone and cyclosporin $A$ on $r I L-1 \beta$ induced IL-8 secretion by orbital fibroblasts detected by ELISA. ${ }^{\star}$ Denotes $p<0.001$ compared with

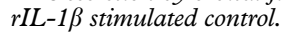

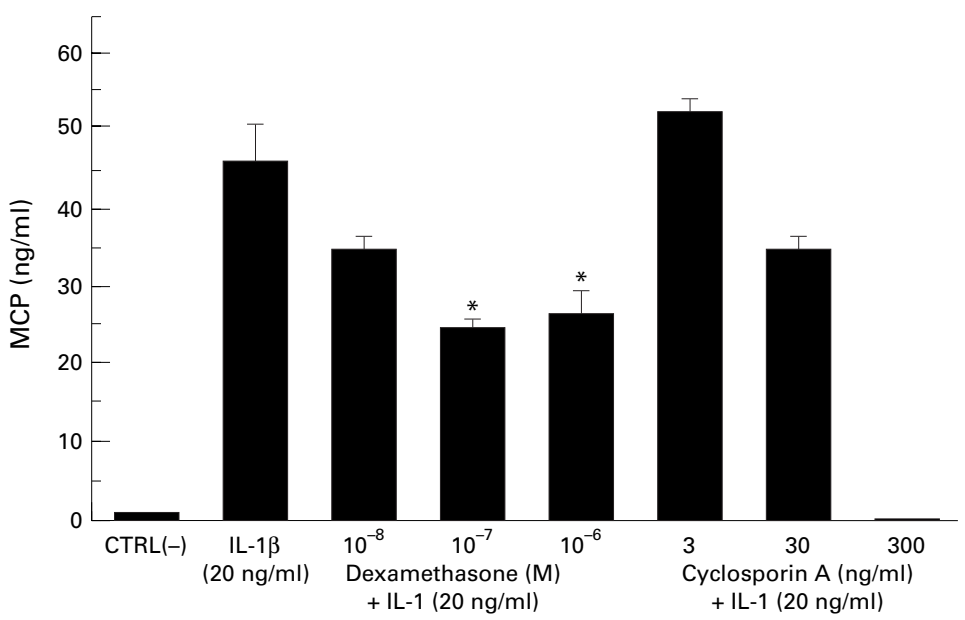

Figure 2 Dose dependent effects of dexamethasone and cyclosporin $A$ on $r I L-1 \beta$ induced $M C P-1$ secretion by orbital fibroblasts detected by ELISA. ${ }^{\star}$ Denotes $p<0.05$ compared with $r I L-1 \beta$ stimulated control.

moderate $(2.0 \mathrm{ng} / \mathrm{ml})$ doses of $\mathrm{rIL}-1 \beta$ induced OF MCP-1, however, were significantly inhibited by CSA (30 ng/ml; p <0.05; Table 1$)$.

NORTHERN BLOT ANALYSIS OF OF IL-8 AND MCP-1 MRNA

OF lacked constitutive IL-8 and MCP-1 mRNA expression (Fig 3). Increased IL-8 and MCP-1 mRNA expression was present following stimulation with $\mathrm{rIL}-1 \beta(20 \mathrm{ng} / \mathrm{ml})$. DEX reduced IL-1 induced IL- 8 and MCP-1 mRNA expression in a dose dependent fashion with greatest reduction noted with $\operatorname{DEX} 10^{-6} \mathrm{M}$. Marked and slightly increased expression of IL-1 induced IL- 8 and MCP-1 mRNA was noted with low doses of CSA ( 3 and $30 \mathrm{ng} / \mathrm{ml}$ ), respectively. At lower concentrations of rIL-1 $\beta$ $\mathrm{OF}$ stimulation $(0.2$ and $2.0 \mathrm{ng} / \mathrm{ml}), \mathrm{DEX}$ decreased IL-8 and MCP-1 steady state mRNA expression (Figs 3 and 4). In contrast, CSA potentiated rIL-1 induced OF IL- 8 mRNA expression and suppressed IL-1 induced MCP-1 mRNA expression (Fig 4). Cell toxicity, as evidenced by cell lysis in culture and lack of extractable RNA, was seen with CSA 300 $\mathrm{ng} / \mathrm{ml}$.

\section{Discussion}

Orbital inflammation is poorly understood. ${ }^{1-4}$ Few models of orbital inflammation exist to explain leucocyte infiltration within the orbit, a complex phenomenon orchestrated by proinflammatory cytokines, cell adhesion molecules, and chemotactic gradients that result in a cascading inflammatory response. By studying ways to attenuate these mechanisms of orbital inflammation, destructive orbital inflammatory processes may be controlled. We believe that resident orbital fibroblasts are critical to initiation and propagation of orbital inflammation. Previously, we have shown that OF differentially express intercellular adhesion molecule 1 (ICAM-1) and HLA-DR antigen ${ }^{15}$ and chemokines (IL-8 and MCP-1) in response to different proinflammatory stimulation (LPS, rIL$1 \beta$, rTNF- $\alpha$, or rIFN- $\gamma) .^{5}$ Similarly, other investigators have found variable expression of adhesion molecules (ICAM-1 and HLA-DR) and cytokine production (IL- $1 \alpha, \mathrm{TNF} \alpha$, and IFN- $\gamma$ ) in orbital fibroblasts of patients with Graves' disease, a disorder characterised by chronic inflammatory cellular infiltrates and accumulation of excessive hydrophilic glycosaminoglycans (GAGs) within the orbit. ${ }^{16-23}$ This accumulation of inflammatory cellular infiltrates and GAGs in Graves' orbitopathy leads to the clinical manifestations of proptosis, diplopia, periorbital swelling, and inflammation. ${ }^{42}$

Cytokines chemotactic for leucocytes, known as chemokines, are critical in propagating an inflammatory response. Their importance in ocular disease is supported by recent animal studies demonstrating IL- 8 to be an important mediator of experimental intraocular inflammation, ${ }^{25}$ and the detection of MCP-1 and IL-8 in proliferative vitreoretinopathy, ${ }^{26}{ }^{27}$ pseudophakic bullous keratopathy, ${ }^{28}$ and herpetic keratouveitis (Wu et al, presented as a poster at the American Academy of Ophthalmology Annual meeting, Atlanta, 1995). We have previously shown that different proinflammatory stimulants activate different OF derived chemokines. ${ }^{5}$ Specifically,

Table 1 Effects of dexamethasone (DEX) and cyclosporin A (CSA) on orbital fibroblasts (OF) IL-8 and MCP-1 production

\begin{tabular}{|c|c|c|c|c|c|c|}
\hline \multirow[b]{2}{*}{ Stimulant } & \multicolumn{3}{|c|}{ IL-8 (ng/ml) immunosuppressive } & \multicolumn{3}{|c|}{ MCP-1 (ng/ml) immunosuppressive } \\
\hline & None & $D E X\left(10^{-6} M\right)$ & $C S A(30 \mathrm{ng} / \mathrm{ml})$ & None & $\operatorname{DEX}\left(10^{-6} M\right)$ & $C S A(30 \mathrm{ng} / \mathrm{ml})$ \\
\hline None (control) & $13.0(1.8)$ & $13.7(0.6)$ & $12.6(0.7)$ & $8.5(0.1)$ & $5.8(0.4)^{\star}$ & $6.3(0.2)^{\star}$ \\
\hline IL-1 $0.2 \mathrm{ng} / \mathrm{ml}$ & $23.3(3.0)$ & $18.4(1.0)$ & $54.0(7.7)^{\star}$ & $12.1(0.8)$ & $9.6(0.8)$ & $8.2(0.7)^{\star}$ \\
\hline $\mathrm{IL}-12.0 \mathrm{ng} / \mathrm{ml}$ & $61.6(0.8)$ & $33.8(4.0)^{\star}$ & $112.3(1.6)^{\star}$ & $13.2(1.1)$ & $7.4(0.8)^{\star}$ & $6.3(0.3)^{\star}$ \\
\hline $\mathrm{IL}-120 \mathrm{ng} / \mathrm{ml}$ & $78.4(3.1)$ & $38.9(7.6)^{\star}$ & $188.7(31.5)^{\star}$ & $22.6(0.6)$ & $13.9(2.0)^{\star}$ & $21.4(3.4)$ \\
\hline
\end{tabular}

Numbers represent mean concentration (SEM) (ng/ml).

$\star$ Denotes $\mathrm{p}<0.05$ compared with control (unstimulated) or rIL-1 $\beta$ stimulation. 


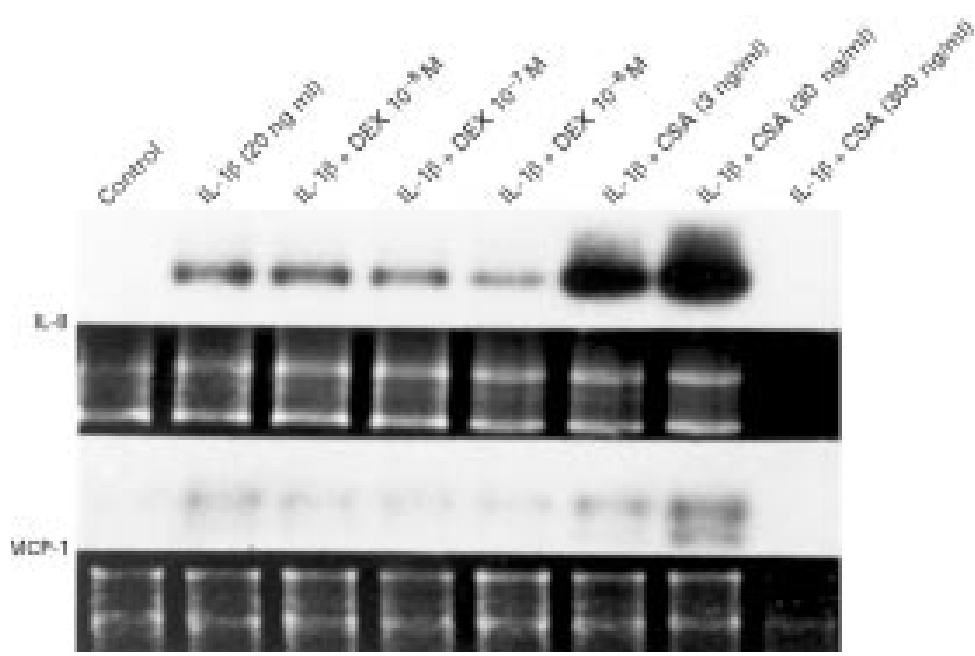

Figure 3 Representative northern blots revealing the effects of dexamethasone (DEX) and cyclosporin $A$ (CSA) on $r I L-1 \beta$ induced $(20 \mathrm{ng} / \mathrm{ml})$ IL-8 and MCP-1 mRNA expression in human orbital fibroblasts at 24 hours. Equivalent total cellular RNA loading per lane is demonstrated by the electrophoretic profile (below) of $18 \mathrm{~s}$ and $28 \mathrm{~s} r \mathrm{RNA}$ in all lanes, except the high dose CSA lane in which cell death occurred from cyclosporin toxicity.
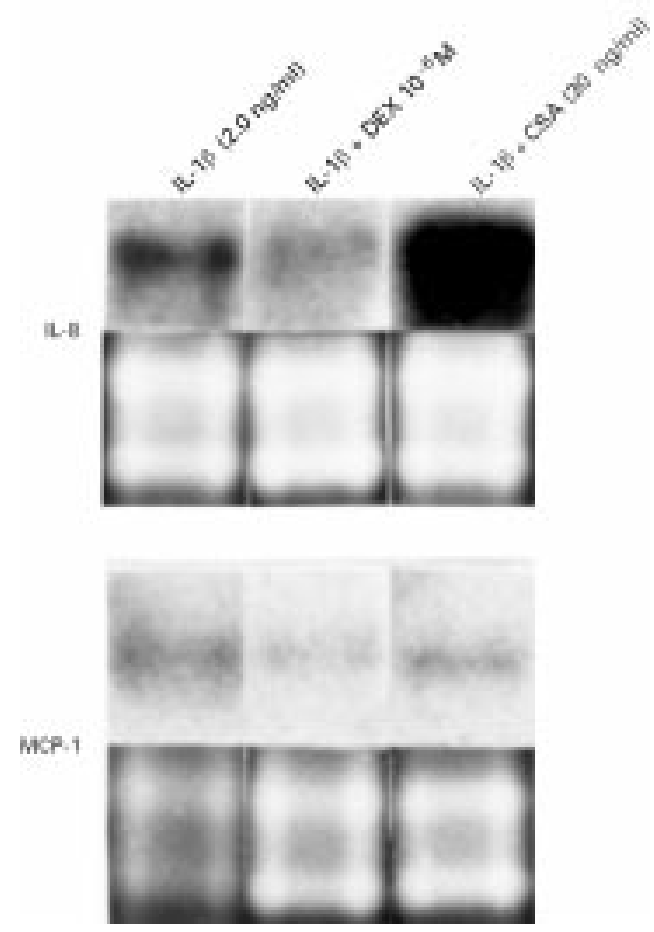

Figure 4 Representative blots revealing the effects of dexamethasone (DEX) and cyclosporin $A(C S A)$ on $O F$ $I L-8$ and $M C P-1 \mathrm{mRNA}$ expression in human orbital fibroblasts at 24 hours in response to rIL-1 $\beta O F$ stimulation $(2.0 \mathrm{ng} / \mathrm{ml})$. Equivalent total cellular $\mathrm{RNA}$ loading per lane is demonstrated by the electrophoretic profile (below) of $18 \mathrm{~s}$ and $28 \mathrm{~s} r \mathrm{rNA}$ in all lanes. Similar results were found with $\mathrm{rIL}-1 \beta(0.2 \mathrm{ng} / \mathrm{ml})$ stimulation (data not shown).

OF lack constitutive IL-8 or MCP-1 secretion or gene expression, but $\mathrm{OF}$ produce substantial dose dependent increases in IL- 8 and MCP-1 secretion and mRNA expression in response to LPS or cytokine stimulation (rIL-1 $\beta>$ rTNF- $\alpha>$ rIFN- $\gamma$ ), emphasising that immune "bystander" OF that reside in orbital tissue participate in orchestrating an orbital inflammatory response by secreting important leucocyte chemotaxins.

In this study, we confirm that $\mathrm{OF}$ produce and secrete IL- 8 and MCP-1 in response to the proinflammatory cytokine IL- $1 \beta$, and we demonstrate that there are widely variable cellular responses to commonly used immunosuppressive agents (DEX and CSA). High rIL-1 $\beta$ concentrations were used to stimulate IL- 8 and MCP-1 so that the dramatic effects of DEX and CSA would be evident. Although IL-1 $\beta$ is usually found at lower concentrations in fluids removed from inflamed tissue, very high local concentrations at the cellular level (microenvironment) may occur. Thus, $20 \mathrm{ng} / \mathrm{ml}$ may be biologically relevant at the sites where actual inflammation occurs. Our study demonstrates that DEX is an effective inhibitor of IL-8 and MCP-1 produced by OF at all rIL- $1 \beta$ concentrations, whereas CSA enhances OF IL-8 production and inhibits OF MCP-1 production at lower rIL-1 $\beta$ concentrations (Table 1 ). These ELISA results are corroborated by northern blot analyses (Figs 3 and 4) and may explain the lack of CSA effectiveness in a wide variety of orbital diseases responsive to corticosteroids. Interestingly, similar results have been reported with the CC chemokine, RANTES: downregulation of RANTES expression by glucocorticoids in $\mathrm{T}$ cells, supporting a putative mechanism for the anti-inflammatory properties of glucocorticoids. ${ }^{29} 30$

Corticosteroids and CSA have numerous anti-inflammatory effects and act by different mechanisms to control inflammation. Corticosteroids cause vasoconstrictive inhibition of leucocyte trafficking, reduction of arachidonic acid derived inflammatory mediators, downregulation of cellular adhesion molecules and proinflammatory cytokine gene transcription (IL-1, IL-2, IFN- $\gamma$, TNF- $\alpha$, IL-6), and destabilisation of cytokine mRNA. ${ }^{31}$ In addition, glucocorticoids inhibit chemokine gene transcription and destabilise chemokine mRNA. ${ }^{32}$ The known anti-inflammatory effects of CSA are less well understood. CSA binds to an intracellular protein receptor, resulting in inhibition of an early calcium dependent signal transduction event involved in lymphokine (IL-2, TNF, and IFN- $\gamma$ ) expression, apoptosis, and degranulation of mast cells, neutrophils, basophils, and cytotoxic T cells. ${ }^{33}$ Since DEX and CSA may have toxic side effects which result in electrolyte, musculoskeletal, gastrointestinal, renal, and neurological abnormalities, ${ }^{34}$ it is important to establish a physiological basis for their use in human disease. Indeed, the enhanced OF IL- 8 gene expression and protein secretion in response to CSA may explain the low therapeutic index of this agent in orbital disease.

Recent studies are defining orbital fibroblasts as potential local immunomodulating cells in the orbit which are able to produce chemokines in response to proinflammatory 
cytokine or LPS stimulation. ${ }^{5}$ Our study describes a mechanism of how DEX may work in orbital inflammatory disorders. Further in vitro and in vivo studies characterising the roles of inflammatory cytokines, cellular adhesion molecules, and chemokines in orbital inflammation may illuminate new approaches that modulate $\mathrm{OF}$ and better control orbital inflammatory disease while reducing treatment associated morbidity. Study of these chemokines in inflammatory disorders is indicated.

Supported by NIH grants EY-09441 (VME; SGE) and

The authors wish to thank Zo-Mei Bian and Mitch Gillet for their technical and intellectual contributions.

1 Rootman J. Diseases of the orbit. Philadelphia: JB Lippincott, 1988:141-280.

2 Kennerdell JS, Dresner SC. The nonspecific orbital inflammatory syndromes. Surv Ophthalmol 1984;29:93-103.

3 White V, Rootman J, Quenville N, et al. Orbital lymphoproliferative and inflammatory lesions. Can $\mathcal{f}$ Ophthalmol 1987;22:362-73.

4 Weetman AP. Thyroid-associated eye disease: pathophysiology. Lancet 1991;338:25-32.

5 Elner VM, Burnstine MA, Kunkel SL, et al. Interleukin-8 and monocyte chemotactic protein-1 gene expression and protein produection by human orbital fibroblasts. Ophthalmic Plastic Reconstruct Surg (in press)

6 Oppenheim JJ, Zachariae COC, Mukaida N, et al. Properties of the novel proinflammatory supergene "intercrine" cytokine family. Annu Rev Immunol 1991;9:617-48.

7 Strieter RM, Koch AE, Antony VB, et al. The immunopathology of chemotactic cytokines: the role of interleukin-8 thology of chemotactic cytokines: the role of interleukin-8 and monocyte che

8 Baggiolini M, Dewald B, Moser B. Interleukin-8 and related chemotactic cytokines- $\mathrm{CXC}$ and $\mathrm{CC}$ chemokines. $A d v$ Immunol 1994;55:97-179.

9 Standford TJ, Kunkel SL, Basha MA, et al. Interleukin-8 gene expression by a pulmonary epithelial cell line: a model for cytokine networks in the lung. F Clin Invest 1990;86 1945-53.

10 Antony VB, Hott JW, Kunkel SL, et al. Pleural mesothelial cell expression of C-C (monocyte chemotactic peptide) and C-X-C (interleukin 8) chemokines. Am 7 Respir Cell Mol Biol 1995;12:581-8.

11 Chirgwin JM, Przybyla AE, MacDonald RJ, et al. Isolation of biologically active RNA from sources enriched in of biologically active RNA from sources
ribonuclease. Biochemistry 1979;18:5294-9.

12 Jonas E, Sargent TD, Dawid IB. Epidermal keratin gene expressed in embryos of Xenopus laevis. Proc Natl Acad Sci expressed in embryc

13 Elner VM, Strieter RM, Elner SG, et al. Neutrophil chemotactic factor (IL-8) gene expression by cytokine-treated retinal pigment epithelial cells. Am f Pathol 1990;136:74550.

14 Elner SG, Strieter RM, Elner VM, et al. Monocyte chemotactic protein gene expression by cytokine-treated hum retinal pigment epithelial cells. Lab Invest 1991;64:819-25.

15 Klett ZG, Elner SG, Elner VM. Differential expression of immunoreactive HLA-DR and ICAM-1 in human cul- tured orbital fibroblasts and orbital tissue. Ophthalmic Plastic Reconstruct Surg 1996;12:153-62.

16 Heufelder AE, Bahn RS. Elevated expression in situ of selectin and immunoglobulin superfamily type adhesion molecules in retroocular connective tissues from patients with Graves' ophthalmopathy. Clin Exp Immunol 1993;91: $381-9$.

17 Heufelder AE, Bahn RS. Graves' immunoglobulins and cytokines stimulate the expression of intercellular adhesion molecule-1 (ICAM-1) in cultured Graves' orbital fibroblasts. Eur f Clin Invest 1992;22:529-37.

18 Bahn RS, Heufelder AE. Retroocular fibroblasts: important effector cells in Graves' ophthalmopathy. Thyroid 1992;2 9-94.

19 Heufelder AE, Smith TJ, Gorman, Bahn RS. Increased induction of HLA-DR by interferon- $\gamma$ in cultured fibroblasts derived from patients with Graves' ophthalmopathy and pretibial dermopathy. $\mathcal{F}$ Clin Endocrinol Metab 1991;73:

20 Heufelder AE, Bahn RS. Detection and localization of cytokine immunoreactivity in retro-ocular connective tissue in Graves' ophthalmopathy. Eur $\mathcal{f}$ Clin Invest 1993;23:10-7.

21 Heufelder AE, Bahn RS. Modulation of Graves' orbital fibroblast proliferation by cytokines and glucocorticoid
receptor agonists. Invest Ophthalmol Vis Sci 1994;35:120-7.

22 Korducki JM, Loftus SJ, Bahn RS. Stimulation of glycosaminoglycan production in cultured human retroglycosaminoglycan production in cultured human retro42.

23 Smith TJ, Bahn RS, Gorman CA, Cheavens M. Stimulation of glycosaminoglycan accumulation by interferon gamma in cultured human retroocular fibroblasts. $\mathcal{F}$ Clin Endocrinol Metab 1991;72:1169-71.

24 Bahn RS, Garrity JA, Gorman CA. Diagnosis and management of Graves' ophthalmopathy. F Clin Endocrinol Metab 1990;71:559-63.

25 Ferrick MR, Thurau SR, Oppenheim MH, et al. Ocular inflammation stimulated by intravitreal interleukin-8 and MCP-1. Invest Ophthalmol Vis Sci 1991;32:1534-9.

26 Elner SG, Elner VM, Jaffe GJ, et al. Cytokines in proliferative diabetic retinopathy and proliferative vitreoretinopathy. Curr Eye Res 1995;14:1045-3.

27 Abu El-Asrar AM, Van Damme J, Put W, et al. Monocyte chemotactic protein-1 in proliferative vitreoretinal disorders. Am f Ophthalmol 1997;123:599-606.

28 Rosenbaum JT, Planck SR, Huang XN, et al. Detection of mRNA for the cytokines, interleukin- $1 \alpha$, and interleukin-8, in corneas from patients with pseudophakic bullous keratopathy. Invest Ophthalmol Vis Sci 1995;36:2151-5.

29 Wingett D, Forcier K, Nielson CP. Glucocorticoidmediated inhibition of RANTES expression in human T lymphocytes. FEBS Lett 1996;398:308-11.

30 Berkman N, Robichaud A, Krishnan VL, et al. Expression of RANTES in human airway epithelial cells: effect of corticosteroids and interleukin $-4,-10$, and -13 . Immunology 1996;87:599-603.

31 Imam AP, Halpern GM. Uses, adverse effects of abuse of corticosteroids. Part I. Allergol Immunopathol 1994;22:250-

32 Nelson PA, Kawamura A, Akselband Y, et al. Effect of immunosuppressive drugs on cytokine gene transcription studied by message amplificaton phenotyping (mapping) polymerase chain reaction. Transplant Proc 1991;23:2867-

3 Wiederrecht G, Lam E, Hung S, et al. The mechansim of action of FK-506 and cyclosporin A. Ann NY Acad Sci 1993;696:9-19.

34 Physicians desk reference. 49th ed. 1995. 